\title{
Identification learning skills on the young prisoners in correctional institution
}

\author{
Gusni $^{1}$, Mudjiran ${ }^{2}$, Syahniar ${ }^{3}$ \\ ${ }^{123}$ Universitas Negeri Padand, Padang - Indonesia, (gusnidian@gmail.com)
}

\begin{abstract}
Young prisoners need non-formal education in order to achieve the targeted teenager's future, because young prisoners have the right to carry out educational. The purpose of this study was to describe learning skills of the young prisoners in correctional institution adolescent Tanjung Pati Lima Puluh Koto. An analyze of the data used instruments learning skills of the young prisoners to 23 teenagers and analysis used is presentation. The research finding showed that learning skills of young prisoners at a medium level. The implication of this research is to identification learning skills young prisoners. In order, the results of this study could be data to assist the prisoners for solving their problems in learning skills, in developing a product to improve learning skills of the young prisoners.
\end{abstract}

Keywords: learning skills, young prisoners

This is an open access article distributed under the Creative Commons 4.0 Attribution License, which permits unrestricted use,

distribution, and reproduction in any medium, provided the original work is properly cited. @2018 by author and Faculty of education, UniversitasNegeri Padang.

\section{Introduction}

Adolescence is a time of transition (Santrock, 2002; Linamarliyah \& Dewi, 2004; Kurniawan, 2009; Maslihah, 2011; Miasari, 2013; Pratama, Syahniar, \& Karneli, 2016) from childhood to adulthood (Kartono, 2005; Laksmiwati, 2011; Batubara, 2016) experiencing developments in all aspects or functions into adolescence (Qomariyah, 2009). Adolescence is a period of storm and stress, which is a turbulent period of conflict and mood swings (Payne, 2012; Arnett, 2006).

Negative experience's juveniles faced by the law vary greatly (Astuti, 2011; Fitriani, 2017). Children in conflict with the law (Sinaga \& Lubis, 2010; Sudarti, 2014), according to the Penitentiary Database System in July 2017 recorded 2,219 child cases of lawlessness committed by children under the age of 16 years in Indonesia.

Based on the results of interviews on July 20, 2017 with officers at the Tanjung Pati Special Institution of Children (LPKA), there were about 29 cases of juvenile delinquency that caused them to stay in custody. Such as theft, violence, drugs, and immoral actions. The age range of inmates ranging from 13 years to 18 years.

The future achievement of adolescents in correctional institutions is also required to assume education or learning, as education should be implemented at all levels of society from an early age, adolescence, adulthood, to old age, including life skills education for inmates serving in prisons. This agrees with Widari (2012) the educational rights of protégés in prisons must still be provided even 
though they are undergoing coaching, deprived of their liberty. Furthermore research mentions non formal ducation programs in prisons, contributes very greatly especially to child prisoners who should at age they still carry formal education, but because of a crime they committed they must be in prison (Akbar, Wijaya, \& Alkonia,2014).

Efforts to facilitate young prisoners in solving learning problems can be through the tutoring service. In this study the objectives to be achieved related to aspects of learning are focused on developing learning skills. In the study Sirait \& Sewu (2015) found that there are concerns of the assisted children when they are rejected by the community after completing the target period if the child is not equipped with skills. Then in terms of education that is disconnected, thus causing lack of information obtained, plus also in LPKA is not allowed to use communication tools with the outside world. It is also an important factor for juvenile inmates developing learning skills in young prisoners.

The problem now is the absence of the implementation of learning skills in LPKA Tanjung Pati which is an important part in the implementation of learning in LPKA. Initial interviews conducted on 4 juvenile inmates at LPKA Tanjung Pati on July 20, 2017 found that in general juvenile inmates were less able to develop learning skills for their future supplies after exiting.

\section{The Basic Concept of Learning Skills}

The through the learning process is an important part (Tahar, 2006; Hakim, 2005) in learning activities to understand and master the subject matter well (Chrisnajanti, 2002, Muhson, 2009). It takes the skills of each individual to make the process maximal and provide satisfactory results (Rahayu, Susanto, \& Yulianti, 2011; kriswoyowati, 2011). Marshak \& Burkle (In Juneja, 2016) Study skills can be defined as learned abilities essential to acquiring knowledge and competence. Study skills emphasize the process of learning." Furthermore Gall (1990:17) "Study skills as the effective use of appropriate techniques for completing a learning task. Furthermore Surya (dalam Adiningtiyas, 2016; Sulistyowati, 2015) reveals that skills are activities that are neoromuscular. Learning skill is the ability to formulate the frame of thinking, attitude and skills to do in a focused and focused step by step to perform an activity or deed.

Learning skills is very effective (Darmayanti, 2015) in understanding the daily lessons and also to increase interest in learning, it is also found during the research Juneja (2016) A lot of research evidence shows that there is a direct co relation between the application and usage of study skills and academic performance of students with learning issues in class. Group of 354 students between the age of 12 and 15, found that high-achieving students are able to recognize the use of good strategies and typically use good study skills over fewer effective study skills.

Learning skills enable students to be students who are able to organize, process, and motivate themselves. In general, the goal of learning skills according to Fahri (2010: 10) is to improve the efficiency and effectiveness of learning, to develop interest and motivation, and to form learners who are independent in learning.

1. Improving the efficiency and effectiveness of learning

Learning of learning skills in this regard is seen as a continuous training process. In exercising the mastery of learning skills all the five senses possessed by everyone are a tool for learning. However, the skills of reading, writing, and recording should be trained into learning skills that support the learning process in mastering the material being studied.

2. Growing interest and motivation

Learning activities need to be done in ways that are effective one of them is the mastery of learning skills, students will have good learning motivation. Sadirman (2007: 75) argues that learning motivation is a non-intellectual psychic factor. His role is in terms of the growth of passion, feel happy and the spirit to learn 
Learning skills not only develop cognitive aspects only, but also involve the development of affective aspects (facing anxiety and anxiety) as well as psychomotor (eye coordination by hand, ear by hand and others). Learning skills are directed toward producing individuals who are capable of learning and self-directed to become an independent learner.

The aspects of learning skills according to Prayitno, Alizamar, Taufik, Syahril \& Karneli (1997: 89) are (1) make a record of time teachers teach (Siagian, 2015; Buzan, 2007); (2) make a summary of the material read (Warouw, 2010), (3) make reports (review reports, discussions, implementation of specific activities), (4) develop ways of answering, (5) preparing papers, (6) effective reading (oral and written), (7) inquiring effectively.

\section{Basic Concept of Adolescent and Teacher Adolescents}

Adolescence is one of the stages or phases of human development. In juvenile terms countries are known as "adolescence" which means to grow into adulthood or in adult development. According to WHO (in Sarwono, 2012), explaining that adolescence is a time when the individual develops from the first time he shows his secondary sexual signs until he reaches sexual maturity; individuals experience psychological development and patterns of identification of children reaching adulthood; a transition from full social-economic dependence to a relatively more independent state. Furthermore, De Brun (in Jahja, 2013) defines adolescence as a period of growth between childhood and adulthood. In line with that opinion Papalia, Olds \& Feldman (2009: 8) also explains that "Adolescence is a transition of development between childhood into adulthood that includes major changes in physical, cognitive, and psychosocial aspects that generally begin at age 11 or 12 years and ends in the late teens or early twenties. During the development of adolescents who undergo many changes and developments, not infrequently teenagers fall into the negative direction, where they perform actions they should not do or perform deviant behavior. This deviant behavior can be regarded as a child delinquency defined by Sarwono (2012: 252) as an act by an immature person who deliberately violates the law and which is known by the child himself that the action was known by the law officer he may be punished.

Misbehavior or child delinquency involves the use and distribution of narcotics, extortion and threats, rape, murder, torture, theft, robbery, sexual harassment, possession of firearms, gambling and embezzlement, which are usually influenced by factors such as neglect of parents in educating, parental disputes or conflicts, parental divorce, disruptive family economic life, unemployment, lack of leisure time, negative association, and so on. These cases are the cause of a teenager getting into a prison house for unlawful behavior and subject to sanctions in the form of punishment. Teenage juvenile inmates where in legal terms are referred to as Criminal Children is a child who based on a court decision underwent a crime in LAPAS Anak at the latest until the age of 18 (eighteen) years (Undang-Undang No. 12 of 1995).

1) According to Priyatno (in Khairina, 2014), the penitentiary system is implemented on the basis of: The principle of protection is the treatment of prisoners in order to protect the community from the possibility of repeated criminal acts by the prisoners of the penitentiary in order to become a useful citizen in society.

2) The principle of equality of treatment and service is the provision of equal treatment and service to the prisoners without differentiating people.

3) The principle of education is that the provision of education and guidance is based on Pancasila, among others: cultivation: (a) kinship spirit, (b) skill, (c) spiritual education, and (d) opportunity to perform worship.

4) The principle of respect for human dignity and prestige is that as a person who goes astray the prisoners of the penitentiary must remain treated as human beings. 
5) The principle of loss of independence is the only suffering is the prisoners should be in prison in a certain time, so have a full chance to fix it because during the penitentiary the built citizens still get other rights like human beings, in other words his or her rights remain protected as health care, eating, drinking, clothing, bedding, skill training, sports and skills.

Learning Skills of Young Prisoners

The skills of adolescent prisoners learning in LPKA Tanjung Pati can be said is still low, young prisoners have not utilize well library that has been provided in LPKA Tanjung Pati, but prisoners rarely come to the library because not yet have good learning skill.

Young prisoners at LPKA Tanjung Pati after interviews with several young prisoners explained that the desire to learn existed. However, less skilled in using the library. While in the library the inmates are confused about how to read, write or concentrate well.

\section{Method}

This research is descriptive (Arikunto, 2010; Yusuf, 2005). This research was conducted at Tanjung Pati Special Institution of Children (LPKA) with total of population were 33 young prisoners, age 1318 years. From the total population, sample use purposive sampling of all young prisoners in correctional institution Tanjung Pati, the sample size of 33 teenegers were young prisoners correlation institution Tanjung Pati.

The collect data, this research used instrument learning skills problems on young prisoners. The questionnaire with nine aspects of skills: reading, writing, listening, remembering, speaking, critical thinking, managing time, concentration. The questionnaire used likert rating with five answer choiches. Data analyzed using descriptive analysis techniques use manual, research limits are only in correctional institution.

\section{Results and Discussion}

\section{Description of Adult Prisoners' Learning Outcomes}

Based on the data processing that has been done, the results of the study are presented and analyzed with the aim of viewing the description of adolescent juvenile learning skills.

Results of research on the field of study 33 adolescent inmates in LPKA Tanjung Pati, it is known that; Teenage prisoners as a whole have learning problems in enough category as many as 20 people with percentage of $60,61 \%$. Teenage prisoners who have learning problems in the high category as many as 9 people with a percentage of $27.27 \%$. Teenage prisoners who have learning problems in the low category as many as 4 people with $12.12 \%$ percentage. There are 9 adolescent inmates having a very high problem in the field of learning, this is the juvenile inmates need guidance from the coach and counselor to overcome the problems seen from the inventory of adolescent juvenile problems.

\section{Highest Data Problem Description in the Learning Field}

Based on the classification of data there are 5 highest score on the problem item of the field of learning of juvenile inmates. 


\begin{tabular}{clllll} 
No & \multicolumn{1}{c}{ Item promblem } & Mean \% Mean Classification Rating \\
\hline 1 & $\begin{array}{l}\text { Want to follow special education or training packages } \\
\text { that support implementation will work }\end{array}$ & 1,76 & 35,15 & Low & 14 \\
\hline 2 & $\begin{array}{l}\text { Felt did not have enough time to add insight, } \\
\text { knowledge, or skill }\end{array}$ & 2,94 & 58,79 & Enough & 12 \\
\hline 3 & Forced or feel compelled to follow vocational training & 4,21 & 84,24 & Very High & 1 \\
\hline 4 & Learning is something that does not really matter in life & 3,39 & 67,88 & High & 6 \\
\hline 5 & Quick bored in reading & 3,39 & 67,88 & High & 7 \\
\hline 6 & reading necessary in life & 2,03 & 40,61 & Cukup & 13 \\
\hline 7 & Not very good at reading a good way & 4,21 & 84,24 & Very High & 2 \\
\hline 8 & $\begin{array}{l}\text { Do not know how to utilize learning resources / library } \\
\text { at LPKA }\end{array}$ & 3,58 & 71,52 & High & 4 \\
\hline 9 & $\begin{array}{l}\text { Less utilize others to ask / discuss about it the less I } \\
\text { understand }\end{array}$ & 3.09 & 61.82 & High & 11 \\
\hline 10 & $\begin{array}{l}\text { It is hard to concentrate on the discussion / explanation } \\
\text { of others }\end{array}$ & 3.15 & 63.03 & High & 10 \\
\hline 11 & Not able to force myself to learn & 3.67 & 73.33 & High & 3 \\
\hline 12 & $\begin{array}{l}\text { It's hard for me to apply the skills acquired in the } \\
\text { laterLP }\end{array}$ & 3.48 & 69.70 & High & 5 \\
\hline 13 & $\begin{array}{l}\text { Tends to take for granted the information obtained } \\
\text { (trusting) }\end{array}$ & 3.36 & 67.27 & High & 8 \\
\hline 14 & $\begin{array}{l}\text { Easily influenced by a variety of information that is not } \\
\text { necessarily true }\end{array}$ & 3.24 & 64.85 & High & 9 \\
\hline
\end{tabular}

\section{Discussion}

The result of inventory processing of learning subject problems on 33 adolescent inmates, it is known that; the highest score on the issue item "Forced or felt forced to follow skills training" and "Not good at reading good", with an average score of 4.21 and $84.24 \%$ percentage included in the category classification is very high. Next on the item "Cannot force yourself to study" problem, with an average score of 3.67 and a percentage of $73.33 \%$ which is included in the high category classification. Furthermore, on the issue item "Do not know how to utilize learning resources / libraries in LPKA", with an average score of 3.58 and a percentage of $71.52 \%$ included in the high category classification. And lastly on the item the problem "It's hard for me to apply the skills acquired in the LP later", with an average score of 3.48 and a percentage of $69.70 \%$ belonging to the high category classification.

The problem young prisoners there are in sufficient classification, this explain that young prisoners do not have yet good learning skills. The problems of young prisoners in the field of learning with a very high classification $(84,24)$ is "Forced or feel forced to follow skills training". The results of Akbar, Wijaya, and Alkonia (2004) by giving soft skills and life skills to juvenile inmates can replace their formal education that is disconnected or have not had time to get and give skills to someone for the better. The problem item "Not good at good reading" is in very high classification $(84,24 \%)$, which means that young prisoners have not had good reading skills yet to know how to read effectively. Reading in the context of learning is an activity to obtain information from something written. Reading is one way to improve and improve the effectiveness of self-inmates (Hastarita, 2013). 
Furthermore the problem item "Cannot force yourself to learn" is high classification (73.33\%), young prisoners mean not yet make learning as a thing in life. Learning is one of the influencing factors and an important role in the personal appearance and behavior of juvenile inmates (Afrida, 2013). Furthermore the problem item "Do not know how to utilize learning resources / libraries in LPKA" is in the high classification (71.52\%). Learning resources as a skill of thinking such as skills to overcome learning and learning resources such as libraries, learning by using resources provide an opportunity for students in this case that is adolescent prisoners to improve motivation to learn, selfdevelopment in learning that allows him to continue learning throughout life (Sudjana, 2007). Item problem "It's hard for me to apply new skills in LP later" is above high $(69,70)$. This shows the learning of inferred lowly inmate prisoners. Learning is very important and great role in improving one's intellectual. (Sukmadinata, 2013) states that learning is done by his or her skills, such as reading, discussing, solving problems, doing tasks, Everyone do have a high learning skill.

\section{Conclusions}

The result showed that, overall, most of the learning skills of young prisoners are at a medium level. Then, showed the importance of learning skills for young prisoners that can be used as provision for young prisoners after completing the term of detention or leaving the penitentiary in order to continue formal education well. For that the existence of learning skills in LPKA which will be expected to affect the desire of young prisoners to continue to study and study despite being in prison. Skills to learn that young prisoners can also use the library well and learn effectively. Learning skills are the ability of individuals to do and solve problems in a process or activity.

\section{References}

Adiningtyas, S. W. (2016). Meningkatkan Keterampilan Belajar Siswa Melalui Layanan Penguasaan Konten. Jurnal Dimensi, 5(3).

Afrida, Y. 2013. "Pengaruh Keterampilan Belajar terhadap Hasil Belajar Mahasiswa Pendidikan Ekonomi Koperasi FKIP Universitas Riau"

Akbar, Wijaya, \& Alkonia. (2014). "Kontribusi Pendidikan Alternatif untuk meningkatkan Soft Skills Narapidana Anak di Lembaga Permasyarakatan Kelas II A Kabupaten Jember". Artikel Ilmiah. Vol I (1):1-4.

Arikunto, S. (2010). Research Procedure A Practical Approach. Jakarta: PT Rineka Reserved.

Arnett, J. J. (2006). G. Stanley Hall's Adolescence: Brilliance and nonsense. History of psychology, 9(3), 186.

Astuti, M. (2011). Anak berhadapan dengan hukum ditinjau dari pola asuhnya dalam keluarga. Sosio Informa, 16(1).

Batubara, J. R. (2016). Adolescent development (perkembangan remaja). Sari Pediatri, 12 (1), 21-9.

Buzan, T. (2007). Buku pintar mind map untuk anak: agar anak jadi pintar di sekolah. Gramedia Pustaka Utama.

Chrisnajanti, W. (2002). Pengaruh Program Remedial terhadap Ketuntasan Belajar Siswa. Jurnal Pendidikan Penabur, 1(1), 81-86.

Darmayanti, T., Rachmatini, M., Karim, F., \& Nurhayati, R. (2015). Studi jangka panjang tentang efektivitas intervensi psikologis dalam meningkatkan kemampuan belajar mandiri dan prestasi belajar mahasiswa pendidikan jarak jauh. Jurnal Pendidikan Terbuka dan Jarak Jauh, 12(1), 1-18.

Database Sistem Pemasyarakatan. (2017). http://smslap.ditjenpas.go.id. (online). Diakses tanggal 15 Agustus 2017. 
Fahri, I. (2010). Memahami Urgensi Keterampilan Belajar dalam pendidikan [online] Vol 4 (12), 110 halaman.. Diakses dari http://www.scribd.com/doc/35820391/Memahami-Urgensi-KeterampilanBelajar-Dalam-Pendidikan pada tanggal 21 Agustus 2017.

Fitriani, I. L. (2017). Islam dan Keadilan Restroratif pada Anak yang Berhadapan dengan Hukum. In right: Jurnal Agama dan Hak Azazi Manusia, 2(1).

Gall, M. D. (1990). Tools for Learning: A Guide to Teaching Study Skills. Association for Supervision and Curriculum Development, Alexandria, VA. (http://files.eric.ed.gov/fulltext/ED320126.pdf).

Hakim, T. (2005). Belajar secara efektif. Niaga Swadaya.

Hastarita, R. D. (2012). Layanan Dasar Bimbingan dan Konseling untuk Mengembangkan Keterampilan Belajar. Bandung: UPI.

Jahja, Y. 2013. Psikologi Perkembangan. Jakarta: Kencana Media Grup.

Juneja, C. (2016). "Study Skills of Learners with Learning Difficulty". International journal of Social Science and Humanities Research. Vol.4, Issue 3, pp: (490-494).

Kartono, M. (2005). Perbandingan Perilaku Agresif Antara Remaja yang Berasal dari Keluarga Bercerai dengan Keluarga Utuh. Jurnal Psikologi Vol, 3(1), 1.

Khairina. 2014. "Pelaksanaan Pola Pembinaan Narapidana Anak Berdasarkan Undang-undang Nomor 12 Tahun 1995 tentang Pemasyarakatan". Laporan penelitian tidak diterbitkan. Batusangkar: STAIN Batusangkar.

Kiswoyowati, A. (2011). Pengaruh motivasi belajar dan kegiatan belajar siswa terhadap kecakapan hidup siswa. Portal Jurnal Universitas Pendidikan Indonesia, 2(1), 12-16.

Kurniawan, T. (2009). Hubungan Antara Interaksi Teman Sebaya Dan Konsep Diri Dengan Intensi Perilaku Seks Pranikah Pada Remaja (Doctoral dissertation), Universitas Muhammadiyah Surakarta).

Laksmiwati, A., \& Ayu, I. (2011). Transformasi sosial dan perilaku reproduksi remaja. Jurnal Studi Jender SRIKANDI, 3(1).

Linamarliyah, F., \& Dewi, R. (2004). Persepsi terhadap dukungan orangtua dan pembuatan keputusan karir remaja. Jounal Provitae, 200459.

Maslihah, S. (2011). Studi tentang hubungan dukungan sosial, penyesuaian sosial di lingkungan sekolah dan prestasi akademik siswa smpit assyfa boarding school subang jawa barat. Jurnal Psikologi Undip, 10(2), 103-114.

Miasari, A. (2013). Hubungan antara komunikasi positif dalam keluarga dengan asertivitas pada siswa SMP Negeri 2 Depok Yogyakarta. EMPATHY Jurnal Fakultas Psikologi, 1(1)

Muhson, A. (2009). Peningkatan Minat Belajar dan Pemahaman Mahasiswa Melalui Penerapan Problem-Based Learning. Jurnal Kependidikan, 39(2).

Papalia, D.E., Olds, S.W., \& Feldman, R.D. (2009). Human Development. Jakarta: Salemba Humanika.

Payne, M. A. (2012). "all gas and no brakes!": Helpful metaphor or harmful stereotype?. Journal of Adolescent Research, 27 (1), 3-17.

Pratama, R., Syahniar, S., \& Karneli, Y. (2016). Perilaku Agresif Siswa dari Keluarga Broken Home. Konselor, 5(4), 238-246.

Prayitno, Alizamar, Taufik, Syahril, \& Elida Prayitno. (1997). Seri Latihan Keterampilan Belajar. Program Studi dan Beban Studi. Satgasus 3SCPD. Tim Pengembangan 3SCPD Proyek PGSM Dikti Depdikbud.

Qomariyah, A. N. (2009). Perilaku penggunaan internet pada kalangan remaja di perkotaan. Universitas Airlangga Surabaya.

Rahayu, E., Susanto, H., \& Yulianti, D. (2011). Pembelajaran sains dengan pendekatan keterampilan proses untuk meningkatkan hasil belajar dan kemampuan berpikir kreatif siswa. Jurnal Pendidikan Fisika Indonesia, 7(2).

Santrock, J. W. (2002). Life-span Development: Perkembangan Masa Hidup. Edisi Kelima. Jilid II. Penerjemah Chusairi dan Damanik. Jakarta.

Sardiman, A. M. (2007). Interaksi dan Motivasi Belajar Mengajar: Bandung. Rajawali Pers. 
Sarwono, S.W. (2012). Pengantar Psikologi Umum. Jakarta: PT Raja Grafindo Persada.

Siagian, R. E. F. (2015). Pengaruh Minat Dan Kebiasaan Belajar Siswa Terrhadap Prestasi Belajar Matematika. Formatif: Jurnal Ilmiah Pendidikan MIPA, 2(2).

Sinaga, S. M., \& Lubis, E. Z. (2010). Perlindungan Hukum terhadap Anak Yang Melakukan Kejahatan dalam Persidangan Anak. JURNAL MERCATORIA, 3(1), 52-57.

Sirait, Y. H., \& Sewu, P. L. S. (2015). Pendidikan Kemandirian dan Keterampilan bagi Anak Binaan di Lembaaga Khusus Pembinaan Anak Sukamiskin. Prosiding SNaPP: Sosial, Ekonomi, dan Humaniora, 5(1), 301-308.

Sudarti, E. (2014). Perlindungan Hukum Terhadap Anak Dalam Proses Ajudikasi. Jurnal Ilmu Hukum Jambi, 2(2).

Sudjana, N., \& Rivai, A.(2007). Teknologi Pengajaran. Bandung: Sinar Baru Algensindo.

Sukmadinata, Nana Syaodih. (2007). Landasan Psikologi Proses Pendidikan. Bandung: Remaja Rosdakarya.

Sulistyowati, A. N. L. (2015). Layanan BimBingan KeLompok untuk Meningkatkan KeterampiLan Belajar Siswa. Edukasia: Jurnal Penelitian Pendidikan Islam, 10(2).

Tahar, Irzan. "Hubungan kemandirian belajar dan hasil belajar pada pendidikan jarak jauh." Jurnal Pendidikan dan Jarak Jauh 7.2 (2006): 91-101.

Undang-Undang No. 12 Tahun 1995 tentang Pemasyarakatan.

Yusuf, A. M. 2005. Metodologi Penelitian (Dasar-Dasar Penyelidikan. Ilmiah). Padang: UNP Press.

Warouw, Z. W. (2010). Pembelajaran Cooperative Script Metakognitif (CSM) yang Memberdayakan Keterampilan Metakognitif dan Hasil Belajar Siswa. In Prosiding Seminar Biologi (Vol. 7, No. 1).

Widari, T. M. (2012). Pemenuhan Hak Pendidikan Anak Didik Pemasyarakatan Di Lembaga Pemasyarakatan Anak. DIH: Jurnal Ilmu Hukum, 8 (15). 